\title{
Family Dynamics of Boys Victims of Sexual Abuse ${ }^{1}$
}

\author{
Amanda Pinheiro Said ${ }^{2}$, Liana Fortunato Costa ${ }^{2}$ \\ ${ }^{2}$ Universidade de Brasília, Brasília-DF, Brazil
}

\begin{abstract}
The family represents a privileged place for the detection of signs and symptoms of violence against children and adolescents, especially against boys, phenomenon underreported. The purpose of this paper was to broaden the understanding about issues related to family dynamics in sexual violence against boys by the use of qualitative method; in order to do so, it was made a documentary research of three cases of boys attended at a health service. Three main axes were highlighted in this article: the importance of family in the disclosure of sexual abuse, stigmas and prejudices, and the proximity of the offenders to the boys. It was observed that family dynamics actively influenced the abusive processes because of its possibility to favor protective or unprotected settings and also for the presence of issues such as transgenerationality and confusion in the family role plays. Thus, it is essential that interventions are also directed to the families, so that they are instructed to better protect the boys.
\end{abstract}

Keywords: sexual abuse, violence, family, gender identity, men

\section{Dinâmicas Familiares de Meninos Vítimas de Abuso Sexual}

Resumo: A família representa estrutura privilegiada para a detecção de sinais e sintomas de violências contra crianças e adolescentes, especialmente contra meninos, em que há grande subnotificação. O objetivo deste estudo foi o de ampliar a compreensão acerca de questões da dinâmica familiar da violência sexual contra meninos por meio da utilização de método qualitativo. Foi realizada uma análise documental de três casos de meninos atendidos em serviço de saúde. Três grandes eixos temáticos destacaram-se nos resultados: importância da família para a revelação do abuso sexual, estigmas e preconceitos que circundam o universo masculino e proximidade dos ofensores com as vítimas representando importante barreira para a revelação. Observou-se que as dinâmicas familiares influenciaram ativamente os processos abusivos, pela possibilidade de favorecer ambientes protetivos ou desprotetivos e também pela presença de aspectos como transgeracionalidade e confusão no exercício dos papéis relacionais. Assim, considera-se fundamental que também às famílias sejam direcionadas intervenções com intuito de instrumentalizá-las para exercerem proteção de maneira mais ampla.

Palavras-chave: abuso sexual, violência, família, identidade de gênero, homens

\section{Las Dinámicas Familiares de Chicos Víctimas de Abuso Sexual}

Resumen: La familia representa una estructura privilegiada en la detección de signos y síntomas de violencias contra niños y adolescentes, sobre todo contra chicos, en que hay una gran subnotificación. Este estudio se propone ampliar el entendimiento acerca de aspectos de la dinámica familiar de la violencia sexual contra chicos, para ello se utilizó el método cualitativo. Se hizo un análisis documental de tres casos de chicos atendidos en un servicio de salud. Se destacaron tres grandes ejes temáticos en los resultados: Importancia de la familia para la revelación del abuso sexual, Estigmas y prejuicios en el universo masculino y Proximidad de los agresores a las víctimas representando una gran barrera para la revelación. Se observó que las dinámicas familiares influyen activamente en los procesos abusivos, debido a la posibilidad de facilitar ambientes protectores o no protectores y también por la presencia de aspectos como la transgeneracionalidad y la confusión en el ejercicio de los papeles relacionales. Se considera fundamental que a las familias también se les dirijan intervenciones con el fin de instrumentalizarlas para ejercer una protección de manera más amplia.

Palabras clave: abuso sexual, violencia, familia, identidad de género, hombres

Although sexual abuse of children and adolescents is a public health issue, so recognized nationally and internationally (Timmerman \& Schreuder, 2014), there are

'Article derived from the master's dissertation of the first author under the supervision of the second, defended in 2017, in the Graduation Program in Clinical Psychology and Culture of the Universidade de Brasília.

Correspondence address: Amanda Pinheiro Said. Universidade de Brasília. Campus Universitário Darcy Ribeiro Asa Norte, Brasília-DF, Brazil. CEP 70.910-900. E-mail: amandapsaid@gmail.com some aspects of this complex phenomenon that need more attention and systematized research. Sexual victimization against boys is one of these aspects still obscured by stigma and silence (Easton, Saltzman, \& Willis, 2014).

Sexual violence against children and adolescents refers to any act or conduct aimed at the sexual satisfaction of an adult or adolescent with a significant age difference to the victim, and may or may not include physical contact and penetration. In child-juvenile sexual offenses, a hierarchical relationship and/or power of the offender is established with 
the victim, since the victim is at a development, cognitive, physical and maturational level inferior to the offender (Moura \& Koller, 2008). Specifically with the male victims, Veenema, Thornton and Corley (2015) present data showing that male victims are more likely to become victims of physically more violent acts if compared to female victims.

It is estimated that the prevalence of boys who have been sexually abused with penetration before age 18 is $5 \%$ and that this number triples when considering other forms of sexual abuse without physical contact (O'Leary, Easton, \& Gould, 2015), such as exhibitionism, voyeurism or exposure to pornography. Although the numbers appear to be low compared to female victims, with prevalences of up to $19.7 \%$ (Pereda, Guilera, Forns, \& Gómez-Benito, 2009), estimates and prevalences of sexual abuse against boys are also questionable, (Murray, Nguyen, \& Cohen, 2014). In this study, the results are presented in Table 1.

In Brazil, both legislation and public health policies have undergone positive changes over the years in order to guarantee comprehensive protection for children and adolescents. Since 1990 , it is mandatory to provide notification of suspected or confirmed situations of violence against children or adolescents (Law No. 8069, 1990); however, it is still possible to notice a Brazilian context that presents difficulties in the accomplishment of this legal norm for reasons ranging from the lack of knowledge of the professionals about the obligation of notification, to the fear that they have to be identified and suffer reprisals, passing for lack of training and formal knowledge of how to perform such procedure (Rates, Melo, Mascarenha, \& Malta, 2015). Such a context has direct implications for the attention and care process that victims of child sexual abuse receive, since the mere existence of laws does not guarantee compliance (Veenema et al., 2015).

Despite the failures and difficulties in the reporting process, it should be noted that the increase in the number of studies discussing sexual violence in developing countries, such as Brazil, does not mean that sexual abuse is a new phenomenon, but rather that the number of notifications is increasing (Veenema et al., 2015). Similarly, it is sexual abuse against male victims, which has been gaining more attention and care from civil society, as well as from services and agecies of protection and guarantee of rights (Hohendorff, Habigzang, \& Koller, 2012).

The short, medium and long term consequences of sexual abuse of male and female victims are diverse, both physically, emotionally, psychologically and socially. The symptoms described as present for both boys and girls are: depression, post-traumatic stress disorder, suicidal ideation, decreased self-esteem (Jong et al., 2015), interpersonal problems, feelings of inferiority, discomfort in relationships with others, anxiety, and risky future sexual behaviors (Maniglio, 2009). However, there are studies that point to some differentiation in consequences depending on the gender of the victim (Hohendorff et al., 2012; Sigurdardottir, Halldorsdottir, \& Bender, 2014).

With the male victims, a more externalizing symptomatology is described than with the female victims, with the predominance of aggressive behaviors, substance abuse (Hohendorff et al., 2012) and feelings of anger; behaviors that are socially expected for the male gender (Sigurdardottir et al., 2014). O'Leary et al. (2015) also cite the fears of male victims about their sexuality, their fear of becoming offenders, and their own prejudice in the selfconcept of male identity.

Considering that the family is one of the main sites of subjective constitution of the subjects (Minuchin, Nichols, $\&$ Lee, 2009) and that it suffers, in turn, important influences of the society in which it is inserted, it reiterates the value that members of family systems have on boys who are victims of sexual abuse. This value is explicit not only in the participation, orientation and supervision that the responsible adults direct to the children, but also because, depending on the family structure and dynamics, this nucleus can be a risk factor for the occurrence of violence.

Costa, Marreco, Barros and Nunes (2015) cite some possible important family risk factors: living in singleparent families or remarried families, living without parents, having alcohol dependent parents, socioeconomic factors, such as belonging to low-income classes, and residing with old people. In this sense, the understanding of the family dynamics is fundamental so that one can better understand the violence suffered and its repercussions. It should be emphasized that belonging to low-income classes is not a risk factor in itself, since exposure to violence transcends social and economic classes (American Psychological Association [APA], 2017). However, community influence on the lives of families is very significant and, because belonging to a context with lack of economic, educational, professional and social resources and opportunities, the community can also become a risk factor.

After surveying national studies on male victims and before the paucity of results, Hohendorff et al. (2012) emphasize the importance of conducting national research that deepens this theme in order to understand the dynamics of sexual violence, the characterization of victims, family members and authors. Considering this Brazilian academic context, lacking research on male victims, this article seeks to broaden the understanding of this phenomenon and contribute to the expansion of knowledge about the dynamics and family structure of such victims, considering the social historical context that they are inserted.

Due to the lack of production that encompasses the family relationships of the male victims of sexual abuse, especially in the moments of childhood, the proposal of this article is that, through a qualitative method, it is possible to examine and to know in greater depth aspects of the dynamics of sexual abuse and family relations of male victims. The objective of this article was, therefore, to expand the understanding about issues of the family dynamics of sexual violence against boys through the use of qualitative method. To do so, we discussed systemic family concepts (Minuchin et al., 2009)-as transgenerationality, exercise of roles, risk factors and protection-in order to emphasize the importance of the understanding, valorization and intervention directed to the relatives of male victims of sexual abuse. The choice of the 
qualitative method aimed also to complement quantitative epidemiological information already collected in the context of the Midwest region for a period of two years (Said \& Costa Jr., 2018). The use of the qualitative component has great value, especially when the data generated from a quantitative approach, such as that of Said and Costa Jr., are insufficient to deepen the complexity of the subjects studied, as is the case of sexual abuse against male victims, thus benefiting from broader analyzes (Glass, Gajwani, \& Turner-Halliday, 2016).

\section{Method}

\section{Participants}

The participants of this study were three male victims of sexual abuse who went through care in a public health institution. No victims were directly accessed and all the information collected from these participants refers to the three medical records of these three selected victims. The institution that served them is part of the Child and Adolescent Protection Network of the Health Department of the region where the research was carried out and has an interdisciplinary team composed of psychology and social service professionals. The three victims arrived at the institution through referral from the Child Protective Service (CPS) of their respective home region and have their main characteristics described in Table 1; in Table 2, the characteristics of the probable offenders of each case are described. The clinical histories of the three families studied are presented below as a way of presenting and characterizing the three participants of this study. It is emphasized that a change of all names was made in order to preserve ethical secrecy.

Table 1

Main Characteristics of Victims

\begin{tabular}{|c|c|c|c|}
\hline Victim & Age & Schooling & Residents in the same household \\
\hline Arthur & 6 & $1^{\text {st }}$ year of Elementary School & Father (31) driver, and mother (33) attendant \\
\hline Caio & 6 to 9 & $6^{\text {th }}$ year Elementary School & Father (48) driver, mother (37) housewife, sister (18) informal work \\
\hline Douglas & 6 years old & $1^{\text {st }}$ year of Elementary School & $\begin{array}{l}\text { Mother (24) housewife, stepfather (24) mason, sister ( } 1 \text { and a half years old), } \\
\text { grandmother (59) housewife, grandfather (62) retired and bar owner }\end{array}$ \\
\hline
\end{tabular}

Table 2

Characteristics of the probable offender(s)

\begin{tabular}{|c|c|c|c|}
\hline $\begin{array}{l}\text { Probable } \\
\text { offender(s) of } \\
\text { each victim }\end{array}$ & Gender & Age & $\begin{array}{l}\text { Relationship/degree of } \\
\text { kinship with the victim }\end{array}$ \\
\hline \multicolumn{4}{|l|}{ Arthur } \\
\hline Offender 1 & M & Legal age & $\begin{array}{l}\text { Arthur's caregiver } \\
\text { grandson }\end{array}$ \\
\hline Offender 2 & M & 21 years old & $\begin{array}{l}\text { Arthur's caregiver } \\
\text { grandson }\end{array}$ \\
\hline \multicolumn{4}{|l|}{ Caio } \\
\hline Offender 1 & M & $\begin{array}{l}3 \text { years older } \\
\text { than Caio }\end{array}$ & Cousin \\
\hline \multicolumn{4}{|l|}{ Douglas } \\
\hline Offender 1 & M & 12 years old & $\begin{array}{l}\text { Neighbor, son of a } \\
\text { family friend couple }\end{array}$ \\
\hline
\end{tabular}

Case 1

Arthur was admitted to the care institution at the age of six, attending the first year of elementary school. Her mother complained of aggressive behavior, speech difficulties and limitations related to the process of learning and socializing of the child. The revelation of the abuse happened while his father was bathing his son and teaching him to wash his penis, Arthur said that Bruno, 22, touched his penis and also asked him to touch Bruno's penis. Arthur is an only child and revealed the abuse in the same year of its occurrence. Faced with the revelation, the parents went to the Child Protective Service and later to the Police Station for Protection of Children and Adolescents (DPCA) and to the Legal Medical Institute (IML) to file a complaint. At the police station, Arthur also reported that Bruno's brother, also of age, was involved in the abuse, and that these occurred more than once, at the grandmother's house of the teenagers, the lady who took care of Arthur. Both teenagers are on the run and so have not been blamed. In the medical record of the institution, there is record of sexual harassment, threats and anal penetration against Arthur. There is a history in Arthur's family of other sexual victimizations perpetrated by the same man, who is now the father-in-law of Arthur's maternal aunt and abused her and two of her sisters, including Arthur's mother, when they were all children. At the time, they tried to tell the mother, but only had credit when two grandchildren, Arthur's cousins, revealed it to the grandmother, four years before the sexual abuse suffered by him. Because he was an older person and recently had a stroke, the family chose not to file a complaint against the offender. Arthur and his parents attended the Multifamiliar Group (Costa, Almeida, Ribeiro, \& Penso, 2009) at the care institution, where it was possible to identify a difficulty of the parents in setting limits with the child. 


\section{Case 2}

Caio was 11 years old and attended the $6^{\text {th }}$ year of Elementary School when he was received at the care institution. There were complaints from his mother that he had a restless, aggressive behavior and that he was afraid of being alone at home, had nightmares and ate too much. The mother discovered the sexual abuse situation when she saw a conversation between her son and his cousin on a social network on the internet, and his cousin, three years older, threatened him and called him a "little fag". The abuses began when Caio was about six years old and took place over three years, at his grandmother's farm, where three houses were built, one of which his cousin resided. It is recorded in the medical record that, besides the threats, there was also anal penetration. In addition to the CPS, the family also reported on the DPCA and Caio was examined at the IML. The contacts between Caio and his cousin were interrupted and the child, together with the parents and his sister, participated in the Multifamily Group in the care institution. During the visits, the teenager's mother reported feelings of extreme guilt and distrust, as she fears that the experience of abuse will influence the child's sexuality. In addition, she began to adopt rigid protective behavior, no longer allowing the child to leave home to play or to other leisure activities.

\section{Case 3}

Douglas was six years old and attended the 1st year of the Elementary School when he was received at the care institution. He resided with his mother, his stepfather, his one-and-a-half-year-old sister and his maternal grandparents and did not know his biological father. The grandparents represented the affective and authority figures, and the mother, Mrs. Estela, reported in the consultations difficulties in imposing limits to the child, using corporal punishment as an educative form. There were complaints that Douglas was a very agitated child, who cried a lot, with restless sleep, presenting aggression with the teacher and colleagues in the school and, also, with the exacerbated sexuality, making sexual jokes with the colleagues. Mrs. Estela witnessed her son with his five-year-old cousin naked and Douglas asking his cousin to "put the dick on his butt." When his mother questioned, Douglas said that Felipe did it to him too. Felipe was 12 years old at the time, a difference of six years, and he was a neighbor of Douglas' family, the son of a family friend. Mrs. Estela let Douglas go play in the adolescent's residence, because she trusted Felipe's parents very much. Douglas says there was only one episode of sexual abuse, but the mother suspects that there were more times, because on more than one occasion the child would come home with toy cars that he earned as a gift from the teenager. The family reported the occurrence at the police station in the area where he lived; Douglas was examined at the IML and at the local health unit, where he received prophylactic care. In the medical record, it was reported that Douglas had already witnessed several episodes of physical and verbal violence among the adults in his family. Douglas's family tries to keep him away from his adolescent neighbor, but sometimes they still met.

\section{Instruments}

The medical records of the institution include the reports of the care given to the victims and their relatives, as well as the records of the procedures performed by the team, such as supervisions and case studies, and other materials, such as the Family Genogram (Carter \& McGoldrick, 1995) and drawings made by the victims. These drawings were performed in a context of care and psychosocial intervention and their contents dealt mainly with the self-image of the victim and their relationship with relatives.

An instrument was built using the Microsoft Excel and Microsoft Word, Windows Operating System tools, to record the information of the medical records in the most uniform way possible. Five large tables containing information about (1) the referral to the care institution, (2) characteristics of the victim, (3) characteristics of the victim's family, (4) the report of sexual abuse, and (5) referrals and flow of institutions.

\section{Procedure}

Data collection. The data collection was based on the medical records of the care institution. Together with the professionals who performed the care, the medical records were thoroughly read and all the information contained therein was transcribed and organized into a database, as explained previously. This procedure occurred in four meetings of about three hours each, in order to ensure the complete transcription of all pertinent information.

The selection of medical record was a convenience sample (Flick, 2009), based on the idea that the case study is a method to illustrate and deepen a theme, thus not needing to have a large sample number (Glass et al., 2016; Grattagliano et al., 2012). The choice of three cases, in a total of just over ten, was made to prioritize cases where the medical records contained more information and were as completely as possible.

Data Analysis. The data analysis had as a theoretical reference the family systems theory (Minuchin et al., 2009), and the information was organized considering the thematic analysis of Minayo (2004), consisting of "discovering the core meanings that compose a communication whose presence or frequency mean something to the analytical objective aimed" (p.209). Initially, the process called floating reading, of all data collected, was done by both researchers. This reading provided the apprehension of the meanings contained in the information to then be assigned the meanings that were the basis of the constitution of the corpus. In this way, all the material was organized, giving rise to three major themes for analysis. 


\section{Ethical Considerations}

After authorization from the care institution, the research project was submitted to the Ethics and Research Committee on Human Beings of the Institute of Human Sciences of the University of Brasília, dated April 1 $1^{\text {st }}, 2015$, having received a favorable opinion with Number 1.009.198.

\section{Results}

The family nucleus plays a fundamental role in the dynamics of violence, not only as a participant, but because it can be a risk or protective factor for children and adolescents, depending on their characteristics and structure (Minuchin et al., 2009). The family, together with the school, is one of the privileged places to detect the symptoms of sexual victimization, because it is in these environments that children and adolescents spend much of the day. In Cases 1 and 2 the main complaints came from the mother, and in Case 3 from the school. In addition, it is important to note that conflicts between family members not only indirectly victimize the boys as witnesses, but also may distract the perception of those responsible that they are being violated.

Gender beliefs and stereotypes, which relate masculinity to conceptions of strength, courage and virility, mark the development of boys and influence the reaction - of themselves, their families and society as a whole - in the face of sexual violence. Fear of becoming homosexual after sexual abuse is present, for example, in the speech of Caio's mother (Case 2). Douglas's mother also expressed fears about her son's future, given the sexualized behavior presented by him (Case 3 ).

In all three cases, sex offenders were adolescents who had close ties to the victim's family. In one case the kinship was consanguineous - cousin, in Case 2 - but in the other two cases they were known persons, by whom the families of the victims maintained ties of trust and affection. In Case 1 they were teenagers, children of Arthur's caretaker, and Case 3 was a teenage son of a Douglas' family friend. In all three cases the network that seemed to play a supportive and caring role for families eventually became a network of aggression.

\section{Discussion}

In the first two cases, families were responsible for identifying signs and symptoms of possible sexual violence against their children. Hohendorff, Santos, and Dell'Aglio (2015) distinguish two types of disclosure of sexual abuse: intentional, when the report comes from the victim, and accidental, when some event brings the violence to the surface. In Case 1, the disclosure of the abusive situation was intentional and directed to Arthur's father, and in Case 2 the disclosure was accidental, as the mother discovered the violence when investigating the child's social networks, after being suspicious of the existence of a problem with the behaviors presented by Caio.
The process of disclosing situations of violence against children and adolescents is a difficult task, which can take years to happen, especially if there is a relationship of trust and closeness between the victim and the revealer (Scrandis $\&$ Watt, 2014). The time interval between the occurrence of violence and its disclosure in Case 1 was relatively short, with both episodes occurring in the same year. In addition, Arthur addressed his speech to his father and not to his mother, who in fact reacted in a more hostile manner, which may justify the son's choice and affinity with his father. The mother's hostility, in turn, can be explained by her own experience of sexual abuse in childhood. The transgenerationality marked in this case places the mother in a position of defenselessness in relation to her son, since, as previously a victim herself, she has difficulty noticing the victimization that occurred with Arthur. That is why she also had feelings of guilt and anger more exacerbated than her husband (Carter \& McGoldrick, 1995).

The proximity and consanguinity of the aggressor in Case 2, as well as the longer duration of abusive situations, may have contributed significantly to justify the nondisclosure of Caio's abuse, since the intra-family relationship between offender and victim, as well as the chronicity of abusive situations are aggravating factors of sexual violence (Mathews, Lee, \& Norman, 2016). In this case, as advocated by Hohendorff et al. (2015), the role of the mother is central, since it is from her initial distrust that she begins to pay attention in different situations and take investigative positions, as occurred in this case.

The family dynamics in Case 3 is marked by confusion in the exercise of roles, with grandparents exercising significant authority, even more than Douglas's own mother. Another example of such a confusion of roles is the way the boy calls his grandmother: "Mommy." Douglas's mother became pregnant when a teenager and raised her child in the presence and under the supervision of her parents, since Douglas's biological father never had any contact with her son. The reports of the professionals in the medical record that Mrs. Estela "did not leave the role of daughter and has difficulties in differentiation" demonstrate how fragile the parental exercise of this woman is.

Differentiation is a concept present in Bowen's (1991) theory of individuals' ability to become autonomous and independent of their family. The more differentiated, the more mature is the individual who also ends up experiencing fewer relational conflicts. In understanding that Mrs. Estela could not differentiate completely from her parents, it is possible to attribute the difficulty in the exercise of motherhood to her, with the correct imposition of limits and authority on her son Douglas. She has no income of her own, resides with her parents, even after her second marriage and a second daughter, and her parents are responsible for important aspects of her life, such as the creation of Douglas, her firstborn.

Attention is also drawn to the presence of conflicts and violence among the other members of the family, because while they are going through situations that place them in the roles of victims and offenders, fighting among themselves, 
family members fail to notice the signs and symptoms of victimized children and adolescents. In Case 3, even with symptoms and complaints of Douglas's misbehavior arising from school, the disclosure of the abuse occurred only accidentally when the mother witnessed the child reproducing the abuse situation with the cousin.

Some risk factors for the occurrence of sexual violence in this family nucleus, also cited in the literature (Costa et al., 2015), are: the fact that Douglas did not know his biological father, the common misunderstandings between Mrs. Estela and her companion, as well as situations of physical and verbal violence among other relatives. These factors are important reasons for the delay in the perception by the relatives of the victimization of Douglas; an explicit flag was needed for this child's family to take the necessary protective measures. Even so, they report that there is still some contact between the boy and his sexual offender, indicating the maintenance of a context still at risk for the child.

One of the possible consequences in cases of sexual abuse, especially when the offender is familiar or close, such as those in this study, is the change in routine and family dynamics after disclosure of the violent situation. Baía, Veloso, Magalhães and Dell'Aglio (2013) also mention the denial and retraction components that, although not present in the cases discussed in this article, often occur due to the fear of the family changes arising from the revelation. These changes explain the children's fear of revealing violence, since from this revelation adverse consequences can occur for themselves and for their relatives (Baía et al., 2013). The presence of only one intentional revelation in this study (Case 1) may signal the fear of changing family dynamics and routine.

Such changes and restructurings in the routines of the analyzed families can be observed first when the three boys have been referred to several institutions, including having to undergo exams in the IML, factors that may be considered adverse for them. In addition, in Case 2, Caio was curtailed by his mother in relation to his leisure practices, and in Case 3 Douglas almost interrupted the contacts with the teenager with whom he played, also ending the moments of play and the secondary gains of toy cars he received.

The existence of prejudice is an important obstacle in the dynamics of sexual abuse against male victims, since their existence often stays ahead of the violent experience itself, contributing in a negative way to the interruption and adoption of necessary intervention and treatment measures. In a study of 460 men with a history of childhood sexual abuse, Easton et al. (2014) surveyed the main barriers to disclosure the abusive situation and found that men postponed disclosure motivated by the fear of becoming homosexuals and becoming sexual abusers later. In Case 2, the adoption of rigid protective measures by the mother exemplifies this fear, since the mother believes that, by closing Caio's cycle of coexistence, she can control the external influences her child receives for his socialization and sexual development. This is one of the aspects described by Hohendorff et al. (2015) regarding the repercussions of violence: routine change with restriction and isolation of the victim and the relatives.
Another implication also brought by Hohendorff et al. (2015) talks about hypersexualization. The existence of sexualized behaviors such as those of Douglas, Case 3, says of his previous experience of sexual victimization: reproduction as a repetition of what happened. In addition, his mother also expressed fears about his sexuality, as Douglas played sexual games with his cousin, also a boy. At the age of six, when the abuse began, there are no reports in the medical records of questions regarding the gender identity of boys, as proposed by Valente (2005). Such doubts are possible to be seen, however, in the reports and postures of these children's mothers.

The stigmas surrounding masculinity are striking in our society and often justify the delay in revelation as well. When the victims are male, as in the cases of this article, boys tend to take socially expected attitudes of what constitutes the male world (Hohendorff et al., 2015) and fragility, fear, insecurity and dependence are not part of this behavior. The existence of such beliefs should be continually addressed in families, once the family is the closest people able to intervene adequately in the perceptions that child has of themselves.

In addition, it is still worth noting the result that points to the seriousness of the abuses with male victims, as also pointed out by Hershkowitz (2014) and Scrandis and Watt (2014). In the three cases of this study there are reports of the presence of anal penetration and of threats or coercion towards the boys. Considering that threats could be considered psychological violence, these boys would face a scenario of polyvictimization (Finkelhor, Ormod, Turner, \& Holt, 2009), that is, of being victims of more than one type of violence at the same time. Such phenomenon, concomitant with the seriousness of what it means to have experienced anal penetration with the existence of physical marks on the body, cause more serious consequences and symptoms for these male victims.

All sex offenders of the three on-screen cases are male and have familial and/or affective ties to the victims. Three of the four sex offenders are adolescents or young adults, a result that has been recently discussed (Costa et al., 2015), because early studies of sexual abuse against children and adolescents, being female victims the majority of them, pointed out parents and stepfathers as the main sexual offenders (Valente, 2005). The fact that all sexual offenders are in a psychosexual period still in development may show an educational and communicational failure of the adults towards these young people. Pincolini and Hutz (2014) argue that these adolescents should not only be criminalized but also seen as "victims of an unprotected childhood" (p.303) and that they use children's availability, their authority and age difference to heal their interests and sexual curiosities.

The presence of an offender still considered as a child (Law No. 8.069, 1990) in Case 2 raises the question of what aspects should be considered to have a frame of sexual abuse that differs from experiences of sexual games between peers. One of the important aspects is the age difference between victim and offender (Pincolini \& Hutz, 2014), being three 
years an unequal level of authority between the two parties. Other aspects present in the dynamics of Case 2, and that differentiates it from normal sexual play, is the intentionality, the presence of threats and verbal violence that occurred from the older cousin to the younger.

The question of the bond and proximity between victim and offender is also worth discussing and, although only in Case 2 the bond was consanguineous, it is possible to be considered that they were all cases of intrafamily sexual abuse, because all of them were known people, reliable and with whom the victims had frequent contact. The intrafamily abuse does not necessarily consider only consaguineous bonds (Costa et al., 2015), which is what makes the phenomenon more complex and with more difficult consequences to be accessed and treated (Murray et al. 2014), because it involves confusion and relational ambiguity for the victims. The offenders, in these cases, are people for whom the boys had affection and had regular relations, with healthy and possibly protective attitudes towards the victims: such as playing, hygiene care, gifts, etc. The relational confusion comes precisely from the presence, at the same time, of healthy and protective behaviors and of inadequate and violent behavior.

The expanded view, with the focus of interventions also directed at the ffenders, not only at the victims, is crucial to think about the dynamics of sexual abuse with its full complexity (Costa et al., 2015). Especially in intrafamilial cases, such as those discussed above, it is essential that the entire family is involved in victim protection mechanisms. As the offenders of these cases are still adolescents, they are also entitled to full protection (Law No. 8069, 1990), which can be exercised through the attention and psychosocial care in the network.

In addition to professional intervention, the need for the families to act as protection mechanisms is emphasized. Services and professionals working in the psychosocial areas can once again educate adults and caregivers, but it is their responsability to advise on sexual education and to adequately supervise the children and adolescents in their homes. Thus, the service teams need specific knowledge regarding gender, sexual identity, socialization, among others, so they can act properly in the interventions directed to the family members.

There are many reasons why the familiar approach to the sexual violence issue - or the inclusion of the family in the study and intervention in this issue - should be indicated/valued/confirmed. The revelation of sexual abuse has the property of building a favorable context for the disclosure of other sexual abuses that occurred in previous generations (Marra \& Costa, 2016), often involving several members who have silenced it for many years. On the other hand, this revelation also leads to the appearance of conjugal conflicts (Penso, Costa, Almeida, \& Ribeiro, 2009), provoking a need for several subsystems to be seen with particular attention. Therefore, it can be said that several important themes are associated with the family in situations of sexual violence: transgenerationality, conjugality, fraternity, community, gender.
Family relations can be seen as a condition of protection and also of risk, and the situations discussed in this text show this ambiguity. Add to this the social and communitarian interferences that penetrate these relations. It is recognized that the socioeconomic context around the family should also be included as another interference, which may influence the worsening conditions of violence (APA, 2017). The need for studies and interventions on the sexual violence context to necessarily include the family, in its scope, means the possibility of offering the opportunity for the empowerment of the family, as an instrument for effective protection of victims. It is considered that the family, because it is a natural resource first, especially in cases of intrafamily sexual abuse, should be given priority and support for transforming the dynamics that encourage the emergence of these conflicts.

The importance of this study is firstly addressed by the topic under discussion - sexual abuse of boys - since it is an unknown subject and scarcely publicized nationally and that has specific surveys in certain regions of the country (Hohendorff et al., 2012, 2015). Even in the various international studies (Scrandis \& Watt, 2014; Valente, 2005), there are no texts that discuss in parallel the sexual abuse of boys with the family dynamics to which they are inserted. A few studies have drawn attention to the figure of the sexual offender and their proximity to the victims and their families. In Pincolini and Hutz (2014), for example, comparisons were made between adolescent and adult sex offenders and the invisibility to which those offenders are subjected was discussed. It is argued here, as also discussed by Pincolini and Hutz, the need that the intervention in cases of violence cover all those involved - victims, relatives and offenders especially in cases of intrafamily sexual abuse.

Another contribution of this study is the chosen methodology, even if with some limitations. Since sexual abuse of boys is still an exploratory topic, it is necessary to associate prevalence studies with studies that cover deeper issues. Qualitative method studies, such as this one, therefore, encompass a greater complexity of the phenomenon and also allow the discussion and reflection of interventions. Accessing the contents of the medical records, for example, it was possible not only to know the family dynamics, but also to access the professionals' perceptions of the cases, since there were records of such information.

Regarding the possibilities of future researches, it is necessary to expand the work on this subject with the qualitative contribution. In this paper, the three case studies concerned a specific regional context and, despite the difficulty in accessing cases like these, with a relatively short temporal distance to the violent episode, future work could enlarge the sample so that it could be more diversified and still have the characteristics of being less regionalized. Sample enlargement and diversification can be beneficial as they would also make it possible to use and understand other profiles of male victims with, for example, different age groups, different family characteristics, different profiles of offense and sexual offender. 
The use of documentary research, specifically with medical and, in these cases, psychosocial records, has great value, since they function as a communication vehicle between the professionals of the care services. The medical records should contain all the records of the procedures performed, but this constitutes the main limitation, since the performance and effectiveness of searches depend on the correct and complete registration of the information in the medical records. Mesquita and Deslandes (2013) discuss some of the reasons why there are failures to fill this instrument: professionals' fear of confidentiality breach on the records, a lack of time to fill those records and even a lack of adequate valuation and understanding of their importance.

In this sense, a limitation of this study is the use of a secondary data source with possible flaws and information gaps. It is important to emphasize the importance of continuous enhancing and training on medical records, since they are vital for adequate procedures and care in the services themselves, but also because they are rich sources of research and information (Mesquita \& Deslandes, 2013). Even with limitations, in the case of documentary research in which information was obtained through access to medical records, these tools are considered relevant, especially by the difficulty of access to populations such as the families described here. This difficulty of access does not only refer to care, but mainly to contexts of research (Grattagliano et al., 2012).

\section{References}

American Psychological Association. (2017). Violence and socioeconomical status. Retrieved from http://www.apa. org/pi/ses/resources/publications/factsheet-violence.pdf

Baía, P. A. D., Veloso, M. M. X., Magalhães, C. M. C., \& Dell'Aglio, D. D. (2013). Caracterização da revelação do abuso sexual de crianças e adolescentes: Negação, retratação e fatores associados [Child sexual abuse disclosure characterization: denial, recantation and associated factors]. Temas em Psicologia, 21(1), 193-202. doi:10.9788/TP2013.1-14

Bowen, M.(1991). De la familia al individuo: La diferenciación del sí mismo en el sistema familiar [From the family to the individual: The differentiation of the self in the family system] (B. E. A. Lonné, Trans.). Buenos Aires, Argentina: Paidós. (Original work published 1979).

Carter, B., \& McGoldrick, M. (1995). As mudanças no ciclo de vida familiar: Uma estrutura para terapia familiar [The changing family life cycle: A framework for family therapy] (M. A. V. Veronese, Trans., 2nd ed.). Porto Alegre, RS: Artmed.

Costa, L. F., Almeida, M. C., Ribeiro, M. A., \& Penso, M. A. (2009). Grupo multifamiliar: Espaço para a escuta das famílias em situação de abuso sexual [Multifamiliar group: space for listening to the families in situation of sexual abuse]. Psicologia em Estudo, 14(1), 21-30. doi:10.1590/S1413-73722009000100004
Costa, L. F., Marreco, D. F., Barros, J. F., \& Chaves, M. N. S. G. (2015). Meninos pré-adolescentes que abusam sexualmente de meninos [Preadolescent boys who sexually abuse children]. Acta Psiquiátrica y Psicológica de América Latina, 61(1), 79-87.

Easton, S. D., Saltzman, L. Y., \& Willis, D. G. (2014). "Would you tell under circumstances like that?": Barriers to disclosure of child sexual abuse for men. Psychology of Men \& Masculinity, 15(4), 460-469. doi:10.1037/a0034223

Finkelhor, D., Ormrod, R., Turner, H., \& Holt, M. (2009). Pathways to poly-victimization. Child Maltreatment, 14(4), 316-329. doi:10.1177/1077559509347012

Flick, U. (2009). Introdução à pesquisa qualitativa [Introduction to qualitative research] (J. E. Costa, Trans., 3rd ed.). Porto Alegre, RS: Artmed. (Original work published 1995).

Glass, S., Gajwani, R., \& Turner-Halliday, F. (2016). Does quantitative research in child maltreatment tell the whole story? The need for mixed-methods approaches to explore the effects of maltreatment in infancy. The Scientific World Journal, 2016, 1869673. doi:10.1155/2016/1869673

Grattagliano, I., Owens, J. N., Morton, R. J., Campobasso, C. P., Carabellese, F., \& Catanesi, R. (2012). Female sexual offenders: Five Italian case studies. Agression and Violent Behavior, 17(3), 180-187. doi:10.1016/j.avb.2012.01.001

Hershkowitz, I. (2014). Sexually intrusive behavior among alleged CSA male victims: A prospective study. Sexual Abuse: A Journal of Research and Treatment, 26(3), 291-305. doi:10.1177/1079063213486937

Hohendorff, J. V., Habigzang, L. S., \& Koller, S. H. (2012). Violência sexual contra meninos: Dados epidemiológicos, características e consequências [Sexual violence against boys: epidemiological data, characteristics, and consequences]. Psicologia USP, 23(2), 395-415. doi:10.1590/S0103-65642012005000007

Hohendorff, J. V., Santos, S. S., \& Dell'Aglio, D. D. (2015). Estudo de caso sobre a revelação da violência sexual contra meninos [Case study on the disclosure of male sexual violence]. Contextos Clínicos, 8(1), 46-54. doi:10.4013/ctc.2015.81.05

Jong, R., Alink, L., Bijleveld, C., Finkenauer, C., \& Hendriks, J. (2015). Transition to adulthood of child sexual abuse victims. Agression and Violent Behavior, 24, 175-187. doi:10.1016/j.avb.2015.04.012

Lei $N^{o}$ 8.069, de 13 de julho de 1990. (1990, 16 de julho). Dispõe sobre o Estatuto da Criança e do Adolescente e dá outras providências [Law no 8.069 , from 13th of July, 1990, provides for the Statute of the Child and Adolescent and gives other measures]. Retrieved from http://www.planalto.gov.br/ccivil_03/leis/L8069.htm

Maniglio, R. (2009). The impact of child sexual abuse on health: A systematic review of reviews. Clinical Psychology Review, 29(7), 647-657. doi:10.1016/j.cpr.2009.08.003

Marra, M. M., \& Costa, L. F. (2016). Caracterização do abuso sexual em clientela do CREAS [Characterization of sexual abuse in clientele of CREAS]. Revista Subjetividades, 16(2), 106-117. doi:10.5020/23590777.16.2.105-116 
Mathews, B., Lee, X. J., \& Norman, R. E. (2016). Impact of a new mandatory reporting law on reporting and identification of child sexual abuse: A seven year time trend analysis. Child Abuse \& Neglect, 56, 62-79. doi:10.1016/j.chiabu.2016.04.009

Mesquita, A. N. O., \& Deslandes, S. F. (2013). A construção dos prontuários como expressão da prática dos profissionais de saúde [The construction of medical records as the expression of health professionals' practice]. Saúde e Sociedade, 19(3), 664-673. doi:10.1590/S0104-12902010000300017

Minayo, M. C. S. (2004). O desafio do conhecimento: Pesquisa qualitativa em saúde [The challenge of knowledge: Qualitative research in health]. São Paulo, SP: Hucitec.

Minuchin, S., Nichols, M. P., \& Lee, W. (2009). Famílias e casais: Do sintoma ao sistema. [Assessing families and couples - from symptom to system] (J. D. Mello, Trans.). Porto Alegre, RS: Artmed.

Moura, A. S., \& Koller, S. H. (2008). A criança na visão de homens acusados de abuso sexual: Um estudo sobre distorções cognitivas [The child in the accused men's sexual abuse vision: A study on distorted cognitions]. Psico-USF, 13(1), 85-94. doi:10.1590/S1413-82712008000100011

Murray, L. K., Nguyen, A., \& Cohen, J. A. (2014). Child sexual abuse. Child and Adolescent Psychiatric Clinics of North America, 23(2), 321-337. doi:10.1016/j.chc.2014.01.003

O'Leary, P., Easton, S. C., \& Gould, N. (2015). The effect of child sexual abuse on men: Toward a male sensitive measure. Journal of Interpersonal Violence, 32(3), 423-445. doi:10.1177/0886260515586362

Penso, M. A., Costa, L. F., Almeida, T. M. C., \& Ribeiro, M. A. (2009). Abuso sexual intrafamiliar na perspectiva das relações conjugais e familiares [Intrafamiliar sexual abuse under the perspective of the marital and familiar relations]. Aletheia, (30), 142-157. Retrieved from http://pepsic.bvsalud.org/scielo.php?script=sci_ arttext\&pid=S1413-03942009000200012

Pereda, N., Guilera, G., Forns, M., \& Gómez-Benito, J. (2009). The international epidemiology of child sexual abuse: A continuation of Finkelhor (1994). Child Abuse \& Neglect, 33(6), 331-342. doi:10.1016/j.chiabu.2008.07.007

Pincolini, A. M. F., \& Hutz, C. S. (2014). Abusadores sexuais adultos e adolescentes no sul do Brasil: Pesquisa em denúncias e sentenças judiciais [Sexual offender adults and adolescentes in South of Brazil: research with complaints and veredicts]. Temas em Psicologia, 22(2), 301-311. doi:10.9788/TP2014.2-03

Rates, S. M. M., Melo, E. M., Mascarenhas, M. D. M., \& Malta, D. C. (2015). Violência infantil: Uma análise das notificações compulsórias, Brasil 2011 [Violence agains children: an analysis of mandatory reporting of violence]. Ciência \& Saúde Coletiva, 20(3), 655-665. doi:10.1590/1413-81232015203.15242014
Said, A. P., \& Costa Jr., A. L. (2018). Polivitimização de meninos vitimizados sexualmente: uma análise documental a partir de fichas de notificação [Polyvictimization of sexually abused boys: a documental analysis from mandatory reporting records]. Contextos Clínicos, 11(1), 26-36. doi:10.4013/ctc.2019.111.03

Scrandis, D. A., \& Watt, M. (2014). Child sexual abuse in boys: Implications for primary care. The Journal for Nurse Practitioners, 10(9), 706-713. doi:10.1016/j.nurpra.2014.07.021

Sigurdardottir, S., Halldorsdottir, S., \& Bender, S. S. (2014). Consequences of childhood sexual abuse for health and well-being: Gender similarities and differences. Scandinavian Journal of Public Health, 42(3), 278-286. doi:10.1177/1403494813514645

Timmerman, M. C., \& Schreuder, P. R. (2014). Sexual abuse of children and youth in residential care: An international review. Aggression and Violent Behavior, 19(6), 715-720. doi:10.1016/j.avb.2014.09.001

Valente, S. M. (2005). Sexual abuse of boys. Journal of Child and Adolescent Psychiatric Nursing, 18(1), 10-16. doi:10.1111/j.1744-6171.2005.00005.x

Veenema, T. G., Thornton, C. P., \& Corley, A. (2015). The public health crisis of child sexual abuse in low middle income countries: An integrative review of the literature. International Journal of Nursing Studies, 52(4), 864-881. doi:10.1016/j.ijnurstu.2014.10.017

Amanda Pinheiro Said is a phd ausente of the Universidade de Brasília, Brasília-DF, Brazil.

Liana Fortunato Costa is a Professor of the Universidade de Brasília, Brasília-DF, Brazil.

Authors' Contribution:

All authors made substantial contributions to the conception and design of this study, to data analysis and interpretation, and to the manuscript revision and approval of the final version. All the authors assume public responsability for content of the manuscript.

Received: Jun. 06, 2017

1st Revision: Oct. 23, 2017

2nd Revision: Dec. 26, 2017

Approved: Jan. 26, 2018

How to cite this article:

Said, A. P., \& Costa, L. F. (2019). Family dynamics of boys victims of sexual abuse. Paidéia(Ribeirão Preto), 29, e2908. doi: http://dx.doi.org/10.1590/1982-4327e2908 